Globish (An English-Indonesian journal for English, Education and Culture )

Vol. 9 No.1 January 2020

P-ISSN: 2301-9913, E-ISSN: 2597-9132

DOI: http://dx.doi.org/10.31000/globish.v7i2

\title{
The Influence of Guided Writing Materials Toward Students' Writing Ability of the Fifth Semester Students at English Study Program FKIP UR
}

\author{
Salwa, Kurniati \\ 1,2English Education Study Program of STAIN Bengkalis
}

\begin{abstract}
This study investigated the influence of guided writing materials in students' writing ability at English Study Program FKIP UR in which forty students that simple randomly selected at English Study Program FKIP UR. The instruments used were questionnaire and writing test. Based on the research findings, the responses of questionnaire were coded into interval score by using Likert Scale which showing the students' ability and their opinion in guided writing that consisted of fifteen statements based on six indicators in the form of frequency. On the other side, writing test administered in term of finding the students' writing ability. It was a writing outlining with fifteen listed in the form of brief statements. Before the research revealed, the tried out had been applied in assessing the validation of the instrument by using Pearson Product Moment correlation formula indicated that items were valid. Reliability calculation were performed in Cronbach's Alpha denoted that the instrument was reliable. The instrument can be stated reliable when if it has Cronbach Coefficient is higher than 0.60. based on research findings it can be concluded that: first, the students' writing by using guided writing was categorized into good category 56.2 , second, the mean score of students' writing test is 50.68, it can be stated that students' writing ability is categorized into good category. While $F_{\text {count }}$ is 27.78 and $F_{\text {table }}$ is 4.25 . Based on its criteria, $H_{0}$ is accepted if $F_{\text {table }}<F_{\text {count }}$ and

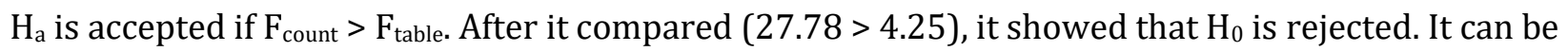
concluded that there was significant influence of guided writing in students' writing ability.
\end{abstract}

Key words; influence, guided writing, ability, students

\section{INTRODUCTION}

Writing is one of language skills that should be mastered by English students, because it is one factor that influences language learning achievement. However, writing ability is affected by 
P-ISSN: 2301-9913, E-ISSN: 2597-9132

DOI: http://dx.doi.org/10.31000/globish.v7i2

other skills and subjects such as listening, grammar, vocabulary, and pronunciation. According to Lerstrom (1990) the development of language skills affects a person's productive ability. Several researchers have elaborated that personal success in disciplines is strongly related to a person's writing ability and depends on good writing skills Cho \& Schunn (2007).

Writing involves understanding many terms including transferring ideas, identifying grammar, exploring vocabulary, grasping meaning and knowledge of structure shows how words are arranged in sentences. Student's limited vocabulary causes the writing activity hard to do. Unknown word makes the students stop and think about meaning of the word. If a student's lack of vocabulary and have trouble in grammatical rules in case of transmitting his or her idea in good order. In brief, writing ability is a reflection of one's mastery of other skills and subjects.

Writing is also influenced by other skills and subjects. However, writing ability can be improved by using variety of materials. Based on Thomas Kral (1993), one solution to help students in writing subjects is by providing different kinds of input English news, short story and so forth. However, unlike courses for other skills, which are mostly paper-based materials, writing courses are a combination of paper-based materials in the form of course book. It means that any resources for writing can be used.

Brindley and Schneider (2002) point out writing instruction should evolve into a more effective set of techniques and strategies that include modeling, shared writing, guided writing, and interactive writing (Pinnell \& Fountas, 1998; Routman, 1991). Regarding the learning strategy to improve writing, Lee (1994) showed how pictures can be used as an effective guided writing strategy to facilitate students' writing process and improve writing proficiency. More specifically, such instruction using pictures in a guided writing environment can assist beginning foreign language students to develop and improve their writing skills.

The present study attempted to combine a guided writing strategy and web-based learning environment to improve the writing environment for enhancing students' writing attitudes. A major feature of the environment is web-based learning can integrate different media, such as text, picture, audio, animation and video to create various multimedia instructional materials and promote the writing interest and willingness of the learner (Gillani \& Relan:1997).

The purposes of this study are: 
P-ISSN: 2301-9913, E-ISSN: 2597-9132

DOI: http://dx.doi.org/10.31000/globish.v7i2

1. To find out the fifth semester students' guided writing materials.

2. To find out the fifth semester students' writing ability.

3. To find out whether there is any significant influence of the fifth semester students' guided writing materials toward students' writing ability.

\section{LITERATURE REVIEW}

Writing skill of second language is not derived naturally; it needs some processes of learning. The processes of writing in the classroom involve a teacher and students. In the classroom the students are given some lists of exercises from a number of materials. Harmer suggests some writing principles (2007:135-136),

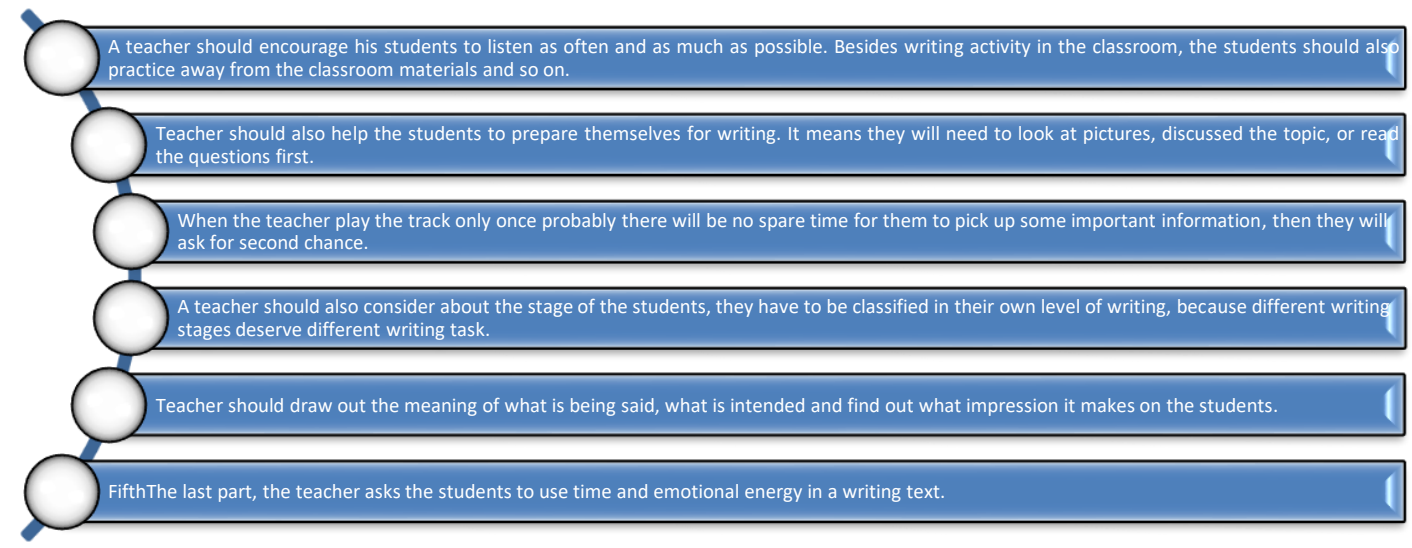

Figure 1 Writing Principle

Writing is not only writing a sentence but it is an activity of producing a text in a context. This idea is also supported by Weigle (2002: 19) who defines writing as an act that takes place within a context, that accomplishes a particular purpose, and that is appropriately shaped for its intended audience. From the definition, it means that it is important to view writing not only as the product of an individual but also as a social act because writing is activities that are socially and culturally shaped and individually and socially purposed.

Writing needs some process of thinking. By knowing the process of writing, students can develop their ability to create a good written text. Brown (2001: 336) states that writing is a process of thinking in which writers figure out their thoughts then put them into written language. During the process of thinking that sometimes needs a long time, the writers are

The Influence of Guided Writing Materials Toward Students' Writing Ability of the Fifth Semester Students at English Study Program FKIP UR

Salwa, Kurniati 
P-ISSN: 2301-9913, E-ISSN: 2597-9132

DOI: http://dx.doi.org/10.31000/globish.v7i2

asked to explore their knowledge, experiences, or memories to find and then determine a topic to write.

Furthermore, Harmer (2004: 6) sees writing as a kind of process wheel, where the writers move both around the circumstance of the wheel and across the spokes. It describes the complex stages that the writers need to go through to write something. Each stage can be continuously repeated until the writers feel no need to go to the previous stages.

\section{A. The Process of Writing}

Hyland (2004:10) states that creative writers have creative ways to express their ideas. During the process of generating and developing ideas, the creativity of the students can be seen, for examples, from the topics they generate and the way they develop the topics. While Brown (2001 : 335) writes that focusing on the process does not mean that the result of writing is not important. The final written product could be the written evidence of the writers' creativity. In other words, it can be said that a good process will lead to a good result. To develop the topics in a good process, there are some ways to go through.

According to Hogue (1999) clarifies that there several stages in writing:

a. Prewriting (choosing/narrowing the topics, brainstorming, and clustering)

b. Planning (Outlining) in case of making sub lists, writing the topic sentence and outlining).

c. Writing and revising drafts (writing the first rough draft, revising content and organization, proofreading the second draft and writing the final copy)

It is shown on the following draft:

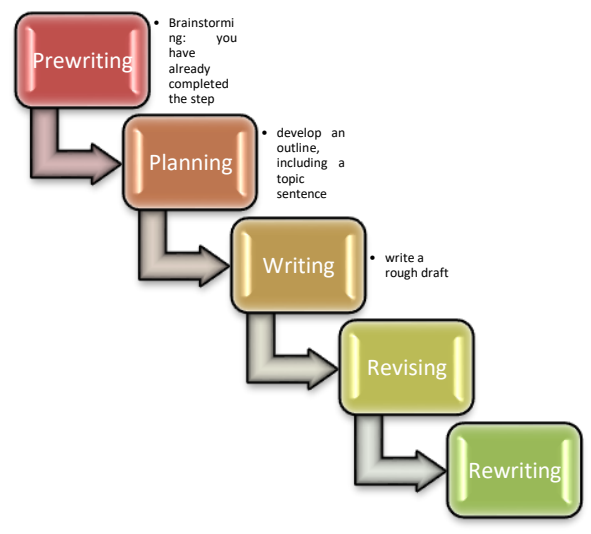

Figure 2: Writing Process Stages 
P-ISSN: 2301-9913, E-ISSN: 2597-9132

DOI: http://dx.doi.org/10.31000/globish.v7i2

\section{b. The Techniques of Teaching Writing}

In order to create an effective writing class, an effective writing method and technique is required. In a foreign language background, English writing will be appropriate to be taught using process approaches rather than product approaches.

\section{Knowledge of Guided Writing}

Guided writing, by definition, is a form of teaching writing in which learners are given step-by-step instruction. Tyner (2004) defines guided writing as an instructional writing context chiefly teaching the writing process through modeling, support, and practice. Guided writing activities help students learn to write by providing them with a partially completed draft or some other form of assistance. Guided writing activities are typically done in the classroom so the teacher can interact with students individually as well as with the entire class.

According to Fountas and Pinnell (2001), guided writing is defined as an instruction presented to small, temporary group of students who share similar needs at a particular point in time. Guided writing provides an important context for teachers' assessment and guidance of student writing to observe students during specific writing events and provide immediate instructional scaffolding for writing processes targeted to the needs of a specific group of students.

Guided writing is the process where teachers develop and guide students' writing through discussion, join text construction and evaluation of their independent writing (Parsons 2001:12). Guided writing involves a teacher working with a group of learners on a writing task. The aims of the task are based on what they have previously been learning about the writing process.

On the other hand, Dunigan (2008:13) states that guided writing is a step by step recipe for writing that includes planning, writing, editing, revising and publishing. Guided writing is an essential component of a balanced writing curriculum, providing an additional supported step towards independent writing. Through guided writing, students are supported during the different stages of the writing process. Guided writing can be fully exploited by providing learners with the language they need to complete the task together with the teacher. It helps them feel certain that they are doing the right thing. 
P-ISSN: 2301-9913, E-ISSN: 2597-9132

DOI: http://dx.doi.org/10.31000/globish.v7i2

\section{d. The Use of Guided Writing}

Guided writing is an important factor in writing strategies. Holdich and Chung (2003) indicate guided writing offers greater opportunities for young writers to make valuable connections between text, sentence and word level decisions and help children shape and redraft texts with particular criteria in mind. Most importantly, with such a writing strategy, the instructor should think how to guide young students into independent writing and help them discover their own abilities by providing opportunities for choice.

Parsons (2001:13) points out there are many use of Guided Writing:

1) Provide a supportive environment for students to practice their writing skills and build confidence.

2) Students understand that one ultimate goal is to take responsibility for their writing and put into practice learned problem-solving strategies

3) Students opportunities to receive immediate teachers' feedback on their writing efforts.

4) Students learn the value of combining their independent writing effort in a group of writing project.

5) Provides a supportive context for specific instruction on the writing tools, for example at the text, sentence, and word level.

6) Motivate students how to manage their writing time.

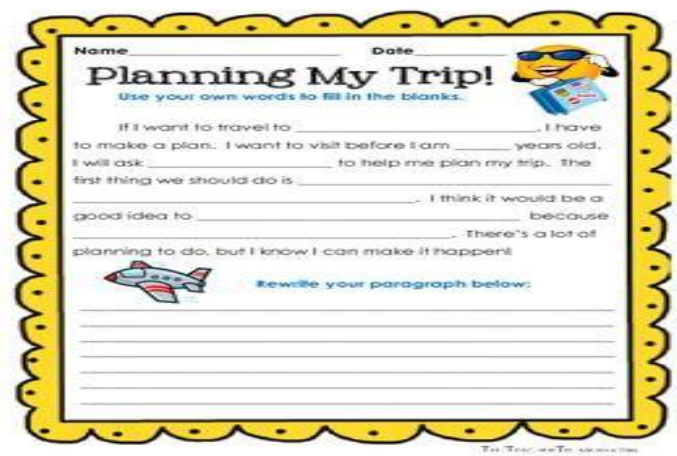


P-ISSN: 2301-9913, E-ISSN: 2597-9132

DOI: http://dx.doi.org/10.31000/globish.v7i2
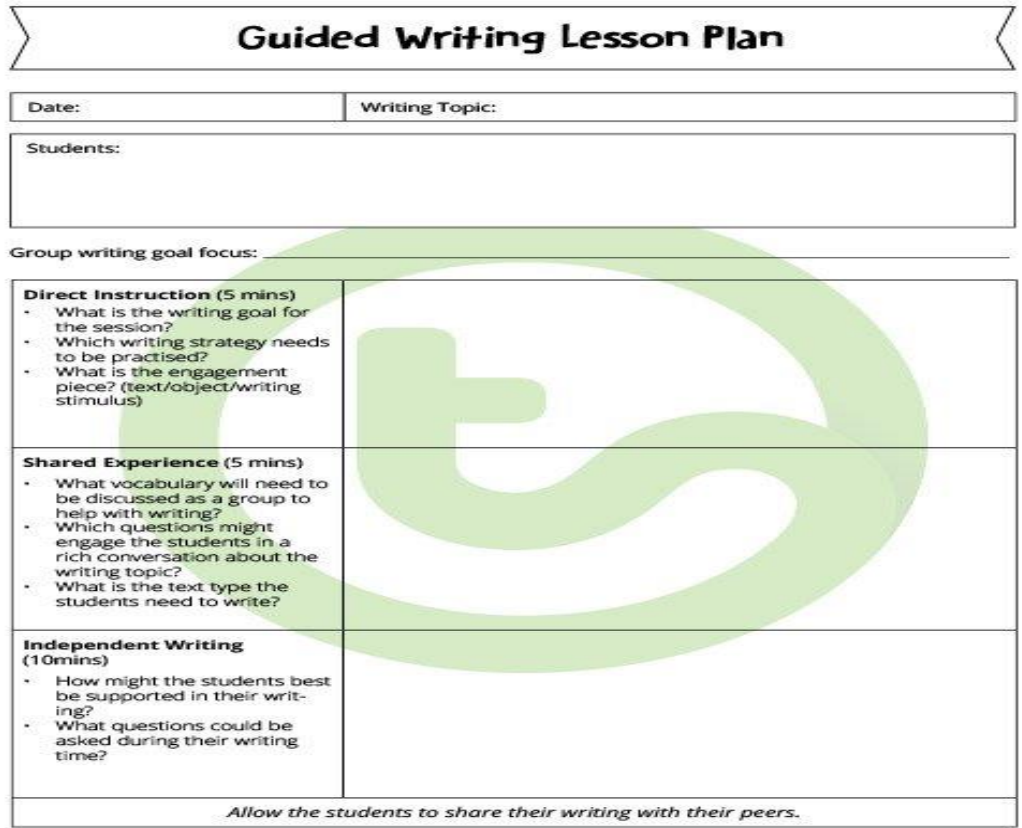

() teachstarter

Tomlinson (1998) explained simplified texts as texts which made simpler for students, in this way they can read/listen them more easily because, there are no long texts, no difficult words and structures, and no additional details. In addition, teachers should provide language materials with different topics in order to preparing students with different situation outside of the classroom (Iravani \& Mousavi, 2012).

\section{PREVIOUS RESEARCH}

Yosep Dwi Anggara. The Effectiveness of Guided Writing in Improving The Students' Writing Ability of The Eighth Grade Students At SMP N 2 Temon in The Academic Year Of $2012 / 2013$. This study is aimed at finding out whether there is a significant difference in the writing ability between grade eight students of SMP Negeri 2 Temon who are taught by using guided writing technique and those who are taught by using a conventional technique in the academic year of 2012/2013. This research was classified as a quasi-experimental study. It involved 61 students from two groups, Class VIII C (30 students) as the control group and Class VIII D (31 students) as the experimental group. The experimental group was taught by using guided writing technique whereas the control group was taught by using a conventional technique. The data were obtained by using two writing tests: pre-test and post-test. The pre-

The Influence of Guided Writing Materials Toward Students' Writing Ability of the Fifth Semester Students at English Study Program FKIP UR 
P-ISSN: 2301-9913, E-ISSN: 2597-9132

DOI: http://dx.doi.org/10.31000/globish.v7i2

test was given to both groups before the treatment and the post-test was given after the treatment. By the result of the hypothesis testing through Ancova. The significance value of 0.002 is less than the significance level of $0.05(0.002<0.05)$, which means that the result of this study are considered to have a significant difference. Therefore, the hypothesis of this study is accepted. It means that the use of guided writing technique significantly improves the students' writing ability in the English teaching and learning process at SMP Negeri 2 Temon.

Yu-Feng LAN Department of Information Management, National Formosa University, Taiwan yflan@nfu.edu.tw. Effects of Guided Writing Strategies On Students'Writing Attitudes Based On Media Richness Theory, Chun-Ling HUNG* Department of Industrial Education and Technology, National Changhua University of Education, Taiwan Department of International Business Administration, Chienkuo Technology University, Taiwan *Corresponding author: hongjl@cc.ctu.edu.tw. The purpose of this paper is to develop different guided writing strategies based on media richness theory and further evaluate the effects of these writing strategies on younger students' writing attitudes in terms of motivation, enjoyment and anxiety. A total of 66 sixth-grade elementary students with an average age of twelve were invited to join the experiment for a period of twelve weeks. A repeated-measure one-way ANOVA analysis was utilized to examine the differences among the three strategies including a rich media guided writing strategy, lean media guided writing strategy, and pen-and-paper guided writing strategy. The findings of this study showed the rich media guided writing strategy had higher significant differences than the pen-and-paper guided writing strategy in terms of writing attitudes toward motivation, enjoyment and anxiety. However, there were no significant differences between the rich media guided writing strategy and lean media guided writing strategy in terms of motivation and anxiety. The findings imply that providing a web-based learning environment with high richness media could guide students to write and achieve more positive writing attitudes in terms of motivation, enjoyment and anxiety.

\section{RESEARCH RESULT AND DISCUSSION}

This research was an ex post facto design or causal-comparative research. Causalcomparative research investigated causal relationships between events and circumstances (Lord Harold G: 1973). 
P-ISSN: 2301-9913, E-ISSN: 2597-9132

DOI: http://dx.doi.org/10.31000/globish.v7i2

\begin{tabular}{c|c|c|c} 
No & Class & Total & Sample \\
\hline 1 & A & 34 & 34 (Try Out) \\
\hline 2 & B & 35 & 20 \\
\hline 3 & C & 32 & 20 \\
\hline \multicolumn{2}{|c|}{ Total } & 101 & 40
\end{tabular}

\section{Instrumentation}

Instrument is used to gauge some qualities or abilities of the subjects. The purpose of the instrument is to elicit the data for our study (Deming:1960). Instrument is the generic term that researcher uses for a measurement device (survey, test, questionnaire, etc.). To help distinguish between instrument and instrumentation, consider that the instrument is the device and instrumentation is the course of action (the process of developing, testing, and using the device).

\section{Validity}

Validity is the extent to which inferences made from assessment results are appropriate, meaningful, and useful in terms of the purpose of the assessment (Gronlund:1998). As a process, validation involves collecting and analyzing data to assess the accuracy of an instrument. Validity consists of four types. They are predictive validity, concurrent validity, construct validity, and content validity or test appropriateness (Tuckman:1978).

Validity can be establishing by relating a test to some actual behavior of which the test is supposed to be predictive. If a test can be used to predict an outcome in terms of some performance or behavior criterion, then the predictive validity of the test can be obtained by relating test performance to subsequent performance on the related criterion. What is usually done in this case is to relate performance on the test with performance on another, well reputed test (if such exists). This procedure is termed concurrent validity. Another procedure for establishing the concurrent validity of a test is to compare qualities or performance as assessed by another procedure. 
P-ISSN: 2301-9913, E-ISSN: 2597-9132

DOI: http://dx.doi.org/10.31000/globish.v7i2

Construct validity is established by relating a presumed measure of a construct or hypothetical quantity with some behavior or manifestation that it is hypothesized to underlined. Moreover, content validity or test appropriateness refers to the appropriateness of the content of an instrument. In other words, do the measures (questions, observation logs, etc.) This would involve taking representative questions from each of the sections of the unit and evaluating them against the desired outcomes. If a test actually samples the subject matter about which conclusions are to be drawn and if it requires the test-taker to perform the behavior that is being measured (Mousavi, 2002: Hughes 2003).

The validity of the questionnaire was counted by correlating the items with the total number of questions. Sudijono (2007:195) points out that if the $r$ value $>$ the value of $r$ table it means that the item is valid, conversely if the $r$ value is $<$ the value of $r$ table it means that the item is invalid.

\section{Reliability}

Test reliability means that a test is consistent (Tuckman:1978). There are four approaches for determining reliability: test-retest reliability, alternate-forms reliability, splithalf reliability, and Kuder-Richardson reliability. Test-retest reliability, the scores obtained by each person on the first administration of the test are related to his or her score on the second administration to provide the reliability coefficient. Alternate-forms reliability is determined by administering alternate forms of a test to the same people or person and computing the relation between each person's score on the two forms. Split-half reliability enables the researcher determines whether the halves of the test are measuring the same quality or characteristics. The obtained correlation coefficient $\left(r_{1}\right)$ is then entered into the Spearman Brown formula to calculate the whole test reliability $\left(r_{2}\right)$.

\section{Data Collection Technique}

The technique of collecting the data in this study was given by a set of questionnaires and writing test to the fifth semester students of English Study Program FKIP UR.

\section{A. Questionnaire}


P-ISSN: 2301-9913, E-ISSN: 2597-9132

DOI: http://dx.doi.org/10.31000/globish.v7i2

As it is stated previously, in order to find out the students' guided writing materials the writer used a set of questionnaires. The questionnaire consisted of 15 items in the form of frequency and agreement. The indicators are:
a. To find out the availability of guided writing materials
b. To relate the students' guided writing to their ability.
c. To realize the importance of exposing guided writing.
d. To identify time spent in elaborating guided writing, and
e. To find out numbers of guided writing that being exposed.

To get the score of the questionnaire the Likert Scale is used. According to Tuckman (1978), a Likert scale is a five-point scale in which the interval between each point on the scale is assumed to be equal. on the basis of the following frequencies. Stanley and Hopkins (1978:288) stated the scales of purposely, vacillating, usually purposeful, effectively motivated, and highly motivated are used in measuring the attitudes. In order to avoid students' misunderstanding, in this study the writer used strongly agree and always to represent highly motivated, agree, and usually to represent effectively motivated, undecided, and often to represent usually purposeful, disagree, and sometimes to represent vacillating, strongly disagree, and never to represent unmotivated. All statements in this questionnaire of this study are in positive form.

Table 1

\section{Responses and Score of the Questionnaire}

\begin{tabular}{|llcc|}
\hline No & Responses & $\begin{array}{c}\text { Implied Meaning of } \\
\text { the Responses }\end{array}$ & Score \\
\hline $\mathbf{1}$ & $\begin{array}{l}\text { Strongly Disagree } \\
\text { Never }\end{array}$ & Unmotivated & 1 \\
\hline $\mathbf{2}$ & Disagree & Vacillating & 2 \\
\hline
\end{tabular}


P-ISSN: 2301-9913, E-ISSN: 2597-9132

DOI: http://dx.doi.org/10.31000/globish.v7i2

\begin{tabular}{|c|c|c|c|}
\hline & Sometimes & & \\
\hline 3 & $\begin{array}{l}\text { Undecided } \\
\text { Often }\end{array}$ & Usually Purposeful & 3 \\
\hline 4 & $\begin{array}{l}\text { Agree } \\
\text { Usually }\end{array}$ & $\begin{array}{l}\text { Effectively } \\
\text { Motivated }\end{array}$ & 4 \\
\hline 5 & $\begin{array}{l}\text { Strongly Agree } \\
\text { Always }\end{array}$ & Highly Motivated & 5 \\
\hline
\end{tabular}

This research was conducted in order to find out whether the students' guided writing materials as independent variable $(x)$ influence students' writing ability as dependent variable $(y)$ on the fifth semester students at English Study Program FKIP UR.

Table 2

Descriptive Statistics of Students' Guided Writing

\begin{tabular}{|c|c|c|}
\hline No & $\begin{array}{c}\text { Descriptive } \\
\text { Analysis }\end{array}$ & Exposure \\
\hline \multirow[t]{2}{*}{1.} & $\mathrm{~N}$ & Valid \\
\hline & & Missing \\
\hline 2. & Mean & 54,1 \\
\hline 3. & Std. Error of Mean & 1,017 \\
\hline 4. & Median & 55 \\
\hline 5. & Mode & $45^{\mathrm{a}}$ \\
\hline 6. & Std. Deviation & 6,432 \\
\hline 7. & Variance & 41,374 \\
\hline 8. & Skewness & $-0,361$ \\
\hline 9. & $\begin{array}{l}\text { Std. Error of } \\
\text { Skewness }\end{array}$ & 0,374 \\
\hline 10. & Kurtosis & $-0,59$ \\
\hline
\end{tabular}


P-ISSN: 2301-9913, E-ISSN: 2597-9132

DOI: http://dx.doi.org/10.31000/globish.v7i2

\begin{tabular}{|clc|}
\hline 11. & $\begin{array}{l}\text { Std. Error of } \\
\text { Kurtosis }\end{array}$ & 0,733 \\
\hline 12. & Minimum & 39 \\
\hline 13. & Maximum & 65 \\
\hline 14. & Sum & 2164 \\
\hline
\end{tabular}

a. Multiple modes exist. The smallest value is shown

The table above shows that score distribution obtained in minimum is 39 and maximum is 65 . Based on the computation of data distribution that the mean score is 54.1 , median is 55 , standard deviation is 6.432. This calculation shows that between mean and median score is not far different. Therefore, those variables distributed normally.

Table 3

\section{Descriptive Statistics of Writing Ability}

\begin{tabular}{|clc|}
\hline No & \multicolumn{1}{c|}{$\begin{array}{c}\text { Descriptive } \\
\text { Analysis }\end{array}$} & \multicolumn{2}{c|}{ Listening } \\
\hline & \multicolumn{1}{c}{$\mathrm{N}$} & Valid 40 \\
\cline { 3 - 3 } 1. & & Missing 0 \\
\hline & & 45,40 \\
\hline 2. & Mean & 1,975 \\
& Std. Error of & \\
\hline 4. & Mean & 47 \\
\hline 5. & Modian & 37 a \\
\hline 6. & Std. Deviation & 12,492 \\
\hline 7. & Variance & 156,041 \\
\hline $\mathbf{8 .}$ & Skewness & $-0,052$ \\
\hline 9. & Std. Error of & 0,374 \\
& Skewness & \\
\hline
\end{tabular}


P-ISSN: 2301-9913, E-ISSN: 2597-9132

DOI: http://dx.doi.org/10.31000/globish.v7i2

\begin{tabular}{|clc|}
\hline 10. & Kurtosis & $-0,254$ \\
\hline 11. & $\begin{array}{l}\text { Std. Error of } \\
\text { Kurtosis }\end{array}$ & 0,733 \\
\hline 12. & Minimum & 20 \\
\hline 13. & Maximum & 70 \\
\hline 14. & Sum & 1816 \\
\hline
\end{tabular}

a. Multiple modes exist. The smallest value is shown

The table above shows that score distribution obtained in minimum is 20 and maximum is 70 . Based on the computation of data distribution that the mean score is 45.40 , median is 47.00 , standard deviation is 12.492 . This calculation shows that between mean and median score is not far different. Therefore, those variables distributed normally.

\section{DATA ANALYSIS}

Test of Normality

The purpose of test normality is to investigate whether the population is distributed normally or not. This kind of test is for measuring interval data, ordinal, or ratio. On this research, the test of normality used in Kolmogorov-Smirnov. The data can be said normal when its significant is bigger than alpha $(\alpha) 0.05$.

The result of normality test can be seen on the score of Kolmogorov-Smirnov that shows on the table below:

Table 4

Tests of Normality

No Variables Kolmogorov-Smirnov ${ }^{a}$


P-ISSN: 2301-9913, E-ISSN: 2597-9132

DOI: http://dx.doi.org/10.31000/globish.v7i2

\begin{tabular}{|cccccc|}
\hline & & Statistic & df & A & Explanation \\
\hline 1. & Guided & 0,091 & 40 &, $200^{*}$ & Normal \\
& Writing & & & & \\
\hline 2. & Writing & 0,076 & 40 &, $200^{*}$ & Normal \\
& Ability & & & & \\
\hline
\end{tabular}

*. This is a lower bound of the true significance.

From the table above the significant score of exposure is 0.200 and listening test is 0.200. Because those variables are bigger than alpha $(\alpha) 0.05$, therefore it can be concluded that the data are distributed normally.

\section{Test of Homogeneity}

It can be stated homogeneity if the score of significant is bigger than alpha $(\alpha) 0.05$, therefore the varian both two groups are similar. The result of test homogenity is shown at table below:

Table 5

Test of Homogeneity of Variances

Students' Guided Writing and Writing Ability

\begin{tabular}{|ccccc|}
\hline $\begin{array}{c}\text { Levene } \\
\text { Statistic }\end{array}$ & df1 & df2 & A & Explanation \\
\hline $\mathbf{3 , 0 2 6}^{\mathbf{a}}$ & 9 & 26 & 0,013 & Homogenous \\
\hline
\end{tabular}

a. Groups with only one case are ignored in computing the test of homogeneity of variance for Exposure.

From the result of test homogeneity shows that the score of significant is 0.013 . It can be stated that the score of significant is more than $\alpha 0.05$. The conclusion is both groups have similar data. The population of each group is distributed similarly. 
P-ISSN: 2301-9913, E-ISSN: 2597-9132

DOI: http://dx.doi.org/10.31000/globish.v7i2

The Result of Coefficients

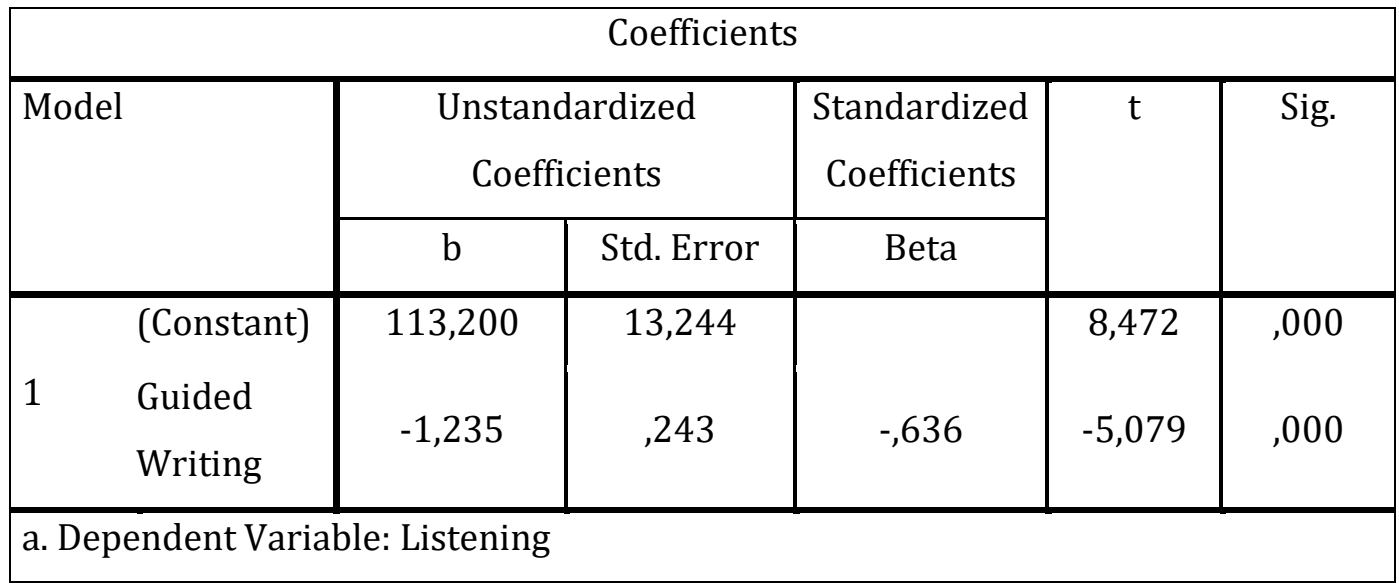

In order to verify the hypothesis, Analysis of Variance (ANOVA) is used for examining the influence of guided writing materials toward writing ability.

The Correlation between students' guided writing material and their writing ability $\mathrm{Y}=$ $113.200+1.235$

Table 6

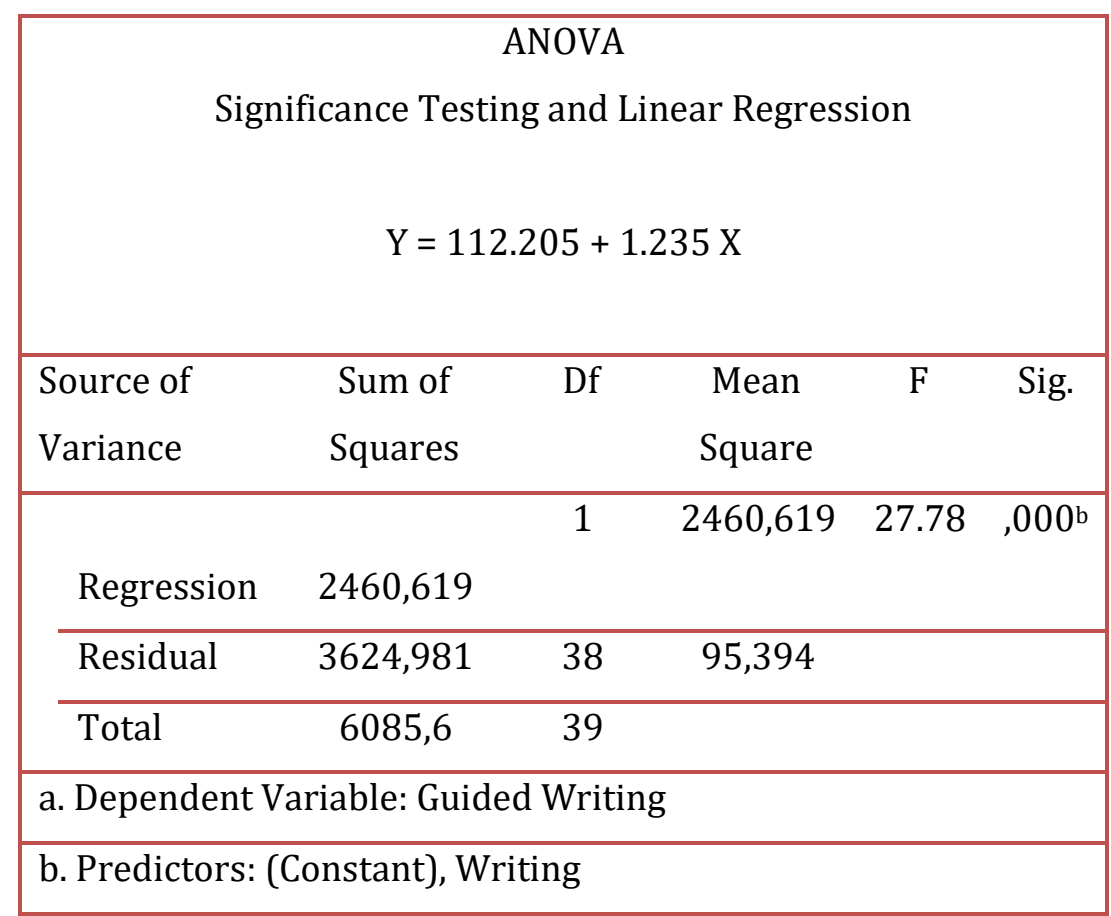


P-ISSN: 2301-9913, E-ISSN: 2597-9132

DOI: http://dx.doi.org/10.31000/globish.v7i2

In the level of significant alpha $(\alpha)$ 0.05. From the ANOVA table that $F_{\text {count }}$ is 27.78 . The

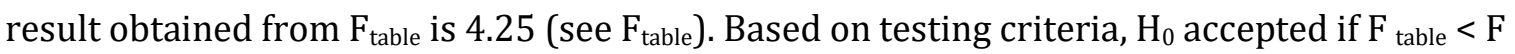
count., and $\mathrm{H}_{1}$ accepted if $\mathrm{F}_{\text {count }}>\mathrm{F}_{\text {table. }}$. After $\mathrm{F}_{\text {count }}>\mathrm{F}_{\text {table }}$ compared $(27.78>4.25)$. The result is $\mathrm{H}_{0}$ rejected. It can be concluded from the computation above that linear regression $\mathrm{Y}=$ $113.200+1.235 \mathrm{X}$ can be used for prediction. The linear regression model presented on the following figure:

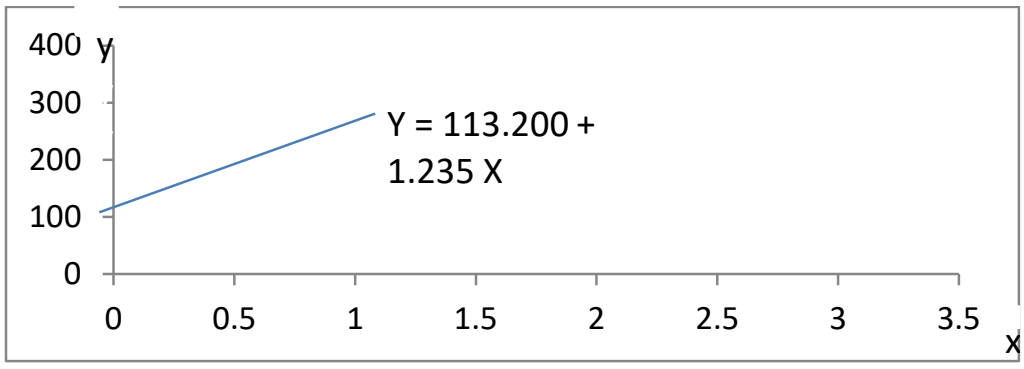

Figure 3: Linear Regression

Then, correlation significant testing is used to identify the significant correlation between students' guided writing materials towards writing ability and examining how is the percentage of influence both variables.

Table 7

\begin{tabular}{|cccc|}
\hline \multicolumn{4}{|c|}{ Correlation Significant Testing } \\
\hline Model & R Square & Adjusted R & Std. \\
& & Square & Error of \\
& & the \\
& & & Estimate \\
& & & 9,767 \\
\hline 1 & $0,636^{\text {a }}$ & & \\
\hline a. Predictors: (Constant), Guided Writing & & \\
\hline
\end{tabular}

The table above shows that $\mathrm{r}$ value $=0.636$ and determinant coefficient $\left(\mathrm{R}_{\text {square }}\right)=$ 0.404 . To find out the contribution from the quadran of $\mathrm{R}_{\text {square }}=40.4 \%$. It indicates that writing ability is influenced by students' guided materials.

From the output of coefficients that $\mathrm{T}_{\text {count }}$ is 5.079. Table $\mathrm{T}_{\text {table }}$ distribution in $\alpha 0.05$. From obtained 2.021. The value of $\left(\mathrm{T}_{\text {count }} 5.079>\mathrm{T}\right.$ table 2.021 so $\mathrm{H}_{1}$ accepted. The conclusion is that there is significant influence of students' guided writing to writing ability. 
P-ISSN: 2301-9913, E-ISSN: 2597-9132

DOI: http://dx.doi.org/10.31000/globish.v7i2

It is proved that in hypothesis testing which is verified bivariate correlation and linear regression. This finding indicates that the variable observed in this study is linear. Therefore, it can be stated that Null hypothesis is rejected and Alternative Hypothesis is accepted.

\section{CONCLUSION}

Based on research findings, it can be concluded that there is significant influence of students' guided writing materials toward writing ability. There are many benefits from the guided writing being used in a real context. Students are highly motivated, giving a sense of achievement when they understand to further writing. The students also reflect the changes in the use of language because there is a wide variety of text types can be used more than once as well as be updated. The role of the teacher is to motivate and guide the students to write any topics that they are interested in, giving the awareness and necessary skills so the students can understand how the language is actually used.

\section{REFERENCES}

Brown, H. Douglas. 2000. The Practice of English Language Teaching Fourth Edition. New York: A Pearson Education Company.

Brown, H. Douglas. 2001. Teaching by Principle: and Interactive Approach to Language Pedagogy Second Edition. New York: A Pearson Education Company.

Duncan, T. G., \& McKeachie, W. J. (2005). The making of the motivated strategies for learning questionnaire. Educational Psychologist, 40(2), 117-128.

Dunigan, Jima. 2008. Classroom Authoring Guided Writing. Teachers Created Resources.

Gibson, A Sharan. 2012. Guided Writing. California: Strategy Guide Series Teaching Writing.

Harmer, Jeremy. 2004. How to teach Writing. Essex: Pearson $\quad$ Education Limited.

Hyland, Ken. 2004. Second Language Writing. Cambridge: Cambridge University Press.

Oczkus, D Lori, 2007. Guided Writing Practical Lesson Powerful Result. Portsmouth: Heinemann.

Parsons, Sharon. 2001. Bookwise 4 Teacher's Guide. Cheltenham: Nelso Thornes Ltd.

Thompson, M. O. (1980). Classroom techniques for reducing writing anxiety: A study of several cases. Paper presented at the annual conference on college composition and 
P-ISSN: 2301-9913, E-ISSN: 2597-9132

DOI: http://dx.doi.org/10.31000/globish.v7i2

communication, Washington, D. C. (ERIC Document Reproduction Service, No. ED 188

661). Thong 